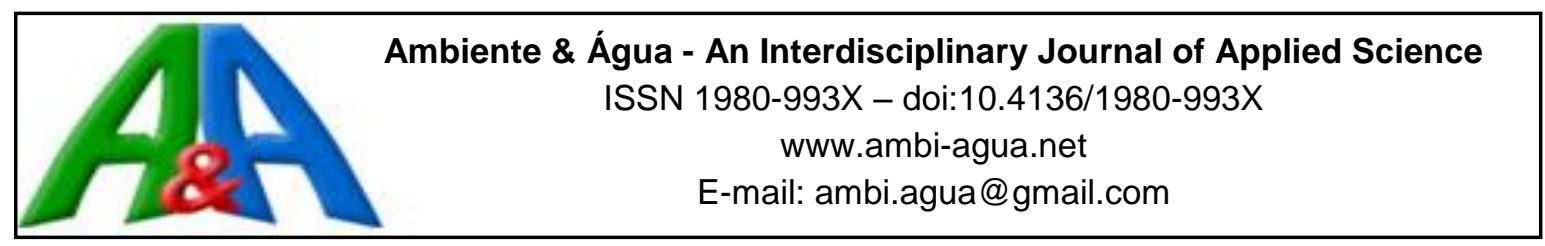

\title{
Importance of adequate appropriation of physiographic information for concentration times determination
}

\author{
ARTICLES doi:10.4136/ambi-agua.2184
}

Received: 19 Sep. 2017; Accepted: 18 Apr. 2018

\author{
Joseline Corrêa Souza; José Antonio Tosta dos Reis*; \\ Antonio Sergio Ferreira Mendonça \\ Universidade Federal do Espírito Santo (UFES), Vitória, ES, Brasil \\ Departamento de Engenharia Ambiental. E-mail: joseline.correa@gmail.com, \\ jatreis@gmail.com, anserfm@terra.com.br \\ *Corresponding author
}

\begin{abstract}
Concentration time is an important parameter for drainage systems design and is closely related to the physiographic characteristics of a given hydrographic basin. Information from cartographic bases or images obtained by remote sensing, which present certain scales/resolutions, are often employed for the appropriation of concentration times. The present study sought to investigate the influence that the combination of different physiographic information, in different scales, and different calculation methods can produce in concentration times' values. The applied methodology included a concentration times appropriation methods survey, identification of methods compatible with the study area characteristics, physiographic variables appropriation from information plans at different scales and concentration times determination for different regions. The results show that there is an equivalence between Tulsa District and US Corps of Engineers methods, and that these methods produce higher concentration times estimates than those produced by the George Ribeiro method. For the study area, the maximum calculated relative error was $52 \%$.
\end{abstract}

Keywords: concentration time, drainage, hydrology, scale, watershed.

\section{Importância de adequada apropriação de informações fisiográficas para definição de tempos de concentração}

\section{RESUMO}

O tempo de concentração representa um importante parâmetro para projetos de drenagem e está intimamente relacionado às características fisiográficas de uma determinada bacia hidrográfica. Para a apropriação de tempos de concentração, muitas vezes são utilizadas informações provenientes de bases cartográficas ou imagens obtidas por sensoriamento remoto, que apresentam determinadas escalas/resoluções. O presente estudo buscou investigar a influência que a combinação de diferentes registros fisiográficos, em diferentes escalas, e diferentes métodos de cálculo podem produzir nos valores dos tempos de concentração. A metodologia empregada consistiu no levantamento de métodos de apropriação de tempos de concentração, identificação dos métodos adequados às características da área de estudo, apropriação das variáveis fisiográficas a partir dos planos de informação em diferentes escalas 
e determinação dos tempos de concentração para as diferentes regiões hidrográficas da área de estudo. Os resultados obtidos mostram que existe equivalência entre os métodos Tulsa District e US Corps of Engineers, e que esses métodos produzem tempos de concentração superiores aos produzidos pelo método de George Ribeiro, produzindo erro relativo com valor máximo de aproximadamente $52 \%$.

Palavras-chave: bacia hidrográfica, drenagem, escala, hidrologia, tempo de concentração.

\section{INTRODUCTION}

Hydrological models are mathematical water systems behavior representations. Among hydrological models, there are the so-called "rainfall-runoff," which represent rainfall transformation processes and consequent flow propagation in a watershed (Fan and Collischonn, 2014).

The rainfall-runoff models are usually used for flow-data series complementation, hydrograph determination for engineering design, flood forecasting and basin land-use assessment (Ferraz et al., 1999). Shuster and Pappas (2010), Halwatura and Najim (2013), Silva et al. (2014), Walsh et al. (2014), Vinagre et al. (2015) and Cabral et al. (2017) illustrate different possible rainfall-runoff models' applications.

The concentration time parameter is necessary for determination of peak flow rates and hydrographs formatting by using rainfall-runoff models (Silveira, 2005; Farias Júnior and Botelho, 2011). Silveira (2005), however, observes that the determination of concentration times is a difficult task due to limited information about the applicability of some of the available empirical formulas.

Concentration times estimation can be done by two approaches: the direct, which uses hydrometeorological records or tracers; and the indirect, which uses previously established mathematical expressions for certain regions. Direct methods are widely utilized when hydrometeorological records with discretization intervals shorter than the concentration time or tracer data collected in field surveys are available (Farias Júnior and Botelho, 2011). In Brazil, however, the availability of information is scarce, especially for medium and small hydrographic basins. Therefore, for this type of regions, the alternative that is usually used for concentration time appropriation is the use of indirect methods.

Mata-Lima et al. (2007) divide the indirect methods formulations' characteristics into two groups: empirical and semi-empirical. According to the authors, the empirical formulations result from correlations and statistical treatment of physiographic variables observed in the field without considering the effect of changes in soil use and occupation, and generally do not require detailed input data. Semi-empirical formulations result from a similar process; however, they also consider the effects of changes in the land use and occupation dynamics and other variables that change over time.

For appropriation of physiographic variables considered in concentration time equations, the use of Geographic Information System (GIS) as a support tool is recurrent. Through GIS it is possible to manipulate digital information plans, available in different scales and resolutions, from which the physiographic variables can be obtained.

The cartographic representation of geographic elements, in paper or digital format, is only possible through using a representation scale. According to Fitz (2008) it is relevant to highlight the fact that when working with digital maps, the scale can easily be transformed to several values. This freedom causes concern about the actual scale represented in digital format. However, the author indicates the need for caution when working with this type of space representation, since the reality represented in a digital map is closely linked to the scale of the information plan that generated it and, therefore, can not assume precision higher than that for 
the original scale.

The present study evaluated the influence of physiographic records scale in hydrographic basins' concentrations time determination. The study area is a medium-sized river basin located in the southwest portion of Espírito Santo state.

\section{STUDY AREA}

The study area consists of a medium-sized hydrographic basin, called Norte Braço Esquerdo River watershed, which presents an area of $333.52 \mathrm{~km}^{2}$ and a perimeter of $111.71 \mathrm{~km}$ and is located in the southwest portion of Espírito Santo state (Caparaó region), Brazil, as can be observed in Figure 1. The watershed has as its main water course the Norte Braço Esquerdo River, an Itapemirim River tributary.

The region presents dry temperate climate, with an average annual rainfall of $1,371 \mathrm{~mm}$, and relief ranging from strongly corrugated to hilly. The predominant soils are classified as Red Latosol and Dystrophic Yellow Latosol, degraded by extensive pastures, degraded crops abandonment, coffee plantations and new annual crops implementation, as well as roads construction and maintenance by using inadequate technologies (INCAPER, 2011).

The basin limits were obtained from the set of Level 5 Ottobacias, available in the Espírito Santo State Geospatial Bases Integrated System (GEOBASES).

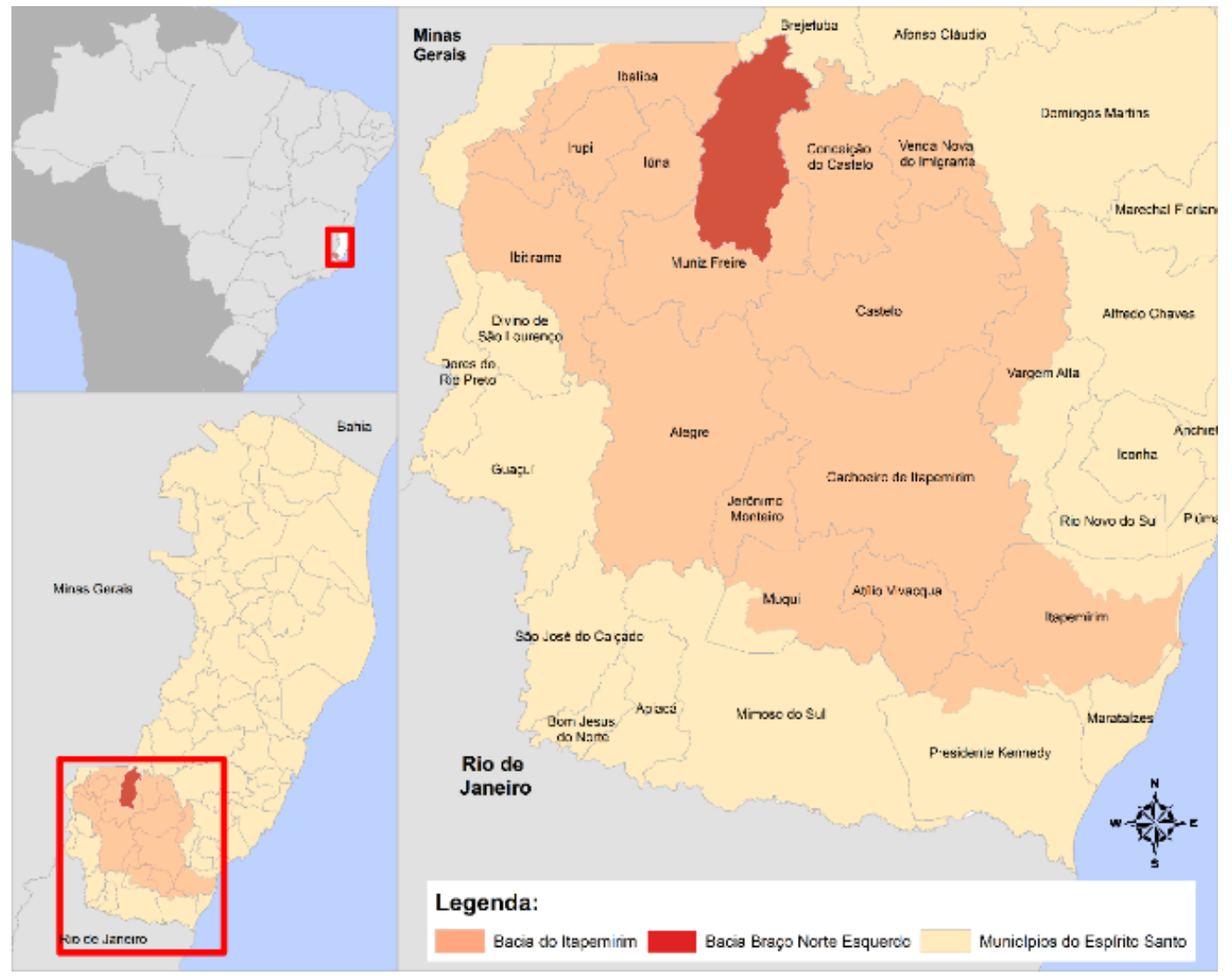

Figure 1. Braço Norte Esquerdo River basin location.

Aiming to make possible comparative analysis of different-sized basins' hydrological response, it was decided to adopt a study area of Level 6 subdivision Ottobacias, available in the GEOBASES database, which present limits compatible with those that are considered for Espírito Santo state water resources planning. In this way, the study area was divided into eight hydrographic basins, whose limits are presented in Figure 2. 


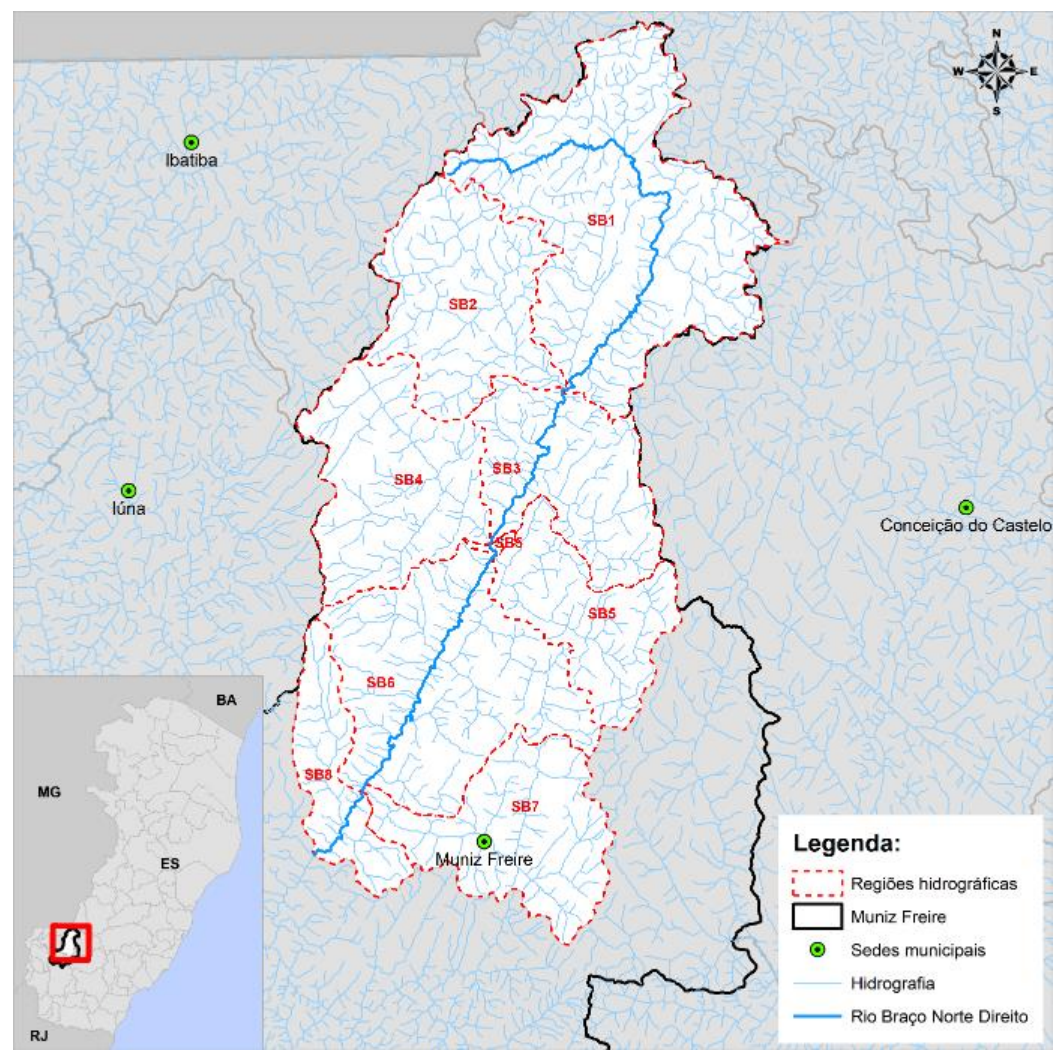

Figure 2. Braço Norte Esquerdo River basin subdivision.

\section{METHODOLOGY}

Two basic assumptions were established for implementing the used methodology different stages:

- Adoption of low-cost and easily reproduced methodologies, prioritizing the use of free computational tools whenever possible; and

- Use of public domain information, free of charge, provided by public institutions.

\subsection{Databases selection}

Physiographic characteristics, which represent the basin's physical characteristics, such as relief, drainage network, vegetation cover, soil and surface use and occupation, among others, are usually extracted from maps, aerial photographs and satellite images. It was decided to use data from digital cartographic bases. In this way, digital files containing information plans in raster or vector format (shapefile format) were manipulated through the Geographic Information System.

In this work, information plans related to relief, drainage network and land use and occupation were used to estimate concentration times. Information plans with dubious origin or low detail level (very small scales) were previously discarded and the other files were submitted to attributes consistency analysis and geometric features representation. This analysis involved information conferencing, file comparison, correction of topological faults and projection systems and coordinates transformations, aiming to work with the data in the same coordinate system and Datum (SIRGAS 2000).

Table 1 summarizes the databases selected for subsequent steps implementation. 
Table 1. Data sources of physiographic information.

\begin{tabular}{|c|c|c|c|c|}
\hline Subject & Geospatial data & Data type & Spatial resolution/scale & Source \\
\hline \multirow{3}{*}{ Relief } & $\begin{array}{l}\text { Digital Elevation } \\
\text { Model }\end{array}$ & Matrix & 90 meters & $\begin{array}{c}\text { Empresa Brasileira de } \\
\text { Pesquisa Agropecuária } \\
\text { (EMBRAPA) }\end{array}$ \\
\hline & $\begin{array}{l}\text { Digital Elevation } \\
\text { Model }\end{array}$ & Matrix & 30 meters & ASTER GEDEM \\
\hline & Level Curves & Vector & $1: 50,000$ & GEOBASES \\
\hline \multirow[b]{2}{*}{$\begin{array}{l}\text { Drainage } \\
\text { network }\end{array}$} & \multirow[b]{2}{*}{ Drainage sections } & Vector & $1: 50,000$ & GEOBASES \\
\hline & & Vector & $1: 250,000$ & $\begin{array}{c}\text { Instituto Brasileiro de } \\
\text { Geografia e Estatística (IBGE) }\end{array}$ \\
\hline $\begin{array}{l}\text { Use and } \\
\text { occupation }\end{array}$ & $\begin{array}{l}\text { Land use (2008- } \\
\text { 2010) }\end{array}$ & Vector & $1: 10,000$ & $\begin{array}{c}\text { Instituto Estadual de Meio } \\
\text { Ambiente e Recursos Hídricos } \\
\text { do Espírito Santo (IEMA) }\end{array}$ \\
\hline
\end{tabular}

\subsection{Concentration times appropriation methods selection}

Existing hydrographic basins' concentration times appropriation methods identification was conducted through a current literature review.

For appropriation methods selection, all methods restrictions were compared with the study area type of occupation, area, slope and talveg length. In this selection stage, three possible outcomes were established:

- Applicable: when all hydrographic basins presented area, slope, talveg length and occupation type within the applicability range established by the concentration time determination method;

- Not applicable: when at least one of the hydrographic basins presented area, slope, talveg length and occupation type outside the applicability range established by concentration time determination method;

- Unidentified restriction: when there was no restriction on the use of the method identified in the revised literature.

\section{RESULTS AND DISCUSSION}

\subsection{Physiographic information}

The equations selected for estimating concentration times involve four variables: a) basin occupation type, b) basin area, c) slope, and d) talveg length. In the subsequent items the cited variables estimated values are presented, considering the different digital cartographic bases used.

\subsubsection{Basin Occupation Type}

Basin occupation type consists of information related to basin predominant land use and occupation, urban or rural. In order to determine the hydrographic basins' occupation types, the areas corresponding to each use class were surveyed by using land use and occupation information plans provided by IEMA in the 1: 10,000 scale. Table 2 was produced from this survey, which presents the percentages of areas associated with different types of land use and occupation.

Table 2 shows that for all hydrographic basins farming activities and forests predominate. The presence of built-up areas is practically negligible in most regions. Only in the SB7 basin do built-up areas occupy approximately $2 \%$. Therefore, all the study area hydrographic basins were classified as rural. 
Table 2. Percentage of area occupied by different land uses and occupation.

\begin{tabular}{lcccccccc}
\hline \multirow{2}{*}{ Land use and occupation } & \multicolumn{7}{c}{ Hydrographic basins } \\
\cline { 2 - 9 } & SB1 & SB2 & SB3 & SB4 & SB5 & SB6 & SB7 & SB8 \\
\hline Rock & 1.95 & 1.87 & 5.89 & 5.72 & 5.61 & 5.74 & 10.10 & 2.20 \\
Built area & 0.05 & 0.00 & 0.49 & 0.00 & 0.00 & 0.28 & 1.91 & 0.00 \\
Swamps & 0.33 & 0.59 & 0.04 & 0.01 & 0.05 & 0.03 & 0.15 & 0.00 \\
Agricultural crop - Banana & 0.03 & 0.00 & 0.00 & 0.00 & 0.00 & 0.00 & 0.00 & 0.00 \\
Agricultural crop - Coffee & 11.74 & 9.10 & 28.39 & 24.61 & 15.09 & 12.06 & 14.02 & 14.90 \\
Agricultural crop - Coconuts & 0.03 & 0.00 & 0.00 & 0.00 & 0.00 & 0.00 & 0.00 & 0.00 \\
Agricultural crop - Other permanent crops & 0.63 & 1.13 & 0.51 & 0.52 & 0.16 & 0.14 & 0.42 & 0.13 \\
Agricultural crop - Other temporary crops & 7.10 & 2.60 & 1.67 & 0.82 & 1.11 & 0.53 & 1.03 & 0.96 \\
Mining & 0.05 & 0.00 & 0.04 & 0.00 & 0.04 & 0.00 & 0.00 & 0.00 \\
Macega & 16.28 & 11.35 & 11.39 & 6.76 & 10.00 & 8.15 & 6.58 & 5.31 \\
Water & 0.11 & 0.07 & 0.29 & 0.00 & 0.11 & 0.34 & 0.03 & 0.46 \\
Native forest & 22.18 & 16.85 & 8.90 & 25.57 & 9.66 & 16.32 & 17.09 & 26.76 \\
Native forest - initial regeneration stage & 5.17 & 7.16 & 3.35 & 8.79 & 3.88 & 6.21 & 7.58 & 7.87 \\
Other & 3.17 & 1.41 & 3.11 & 1.70 & 1.66 & 1.31 & 2.44 & 1.58 \\
Pasture & 22.93 & 31.02 & 32.32 & 20.50 & 50.77 & 47.00 & 37.26 & 38.30 \\
Reforestation - Eucalyptus & 5.73 & 14.79 & 2.47 & 4.30 & 1.59 & 1.20 & 0.78 & 1.29 \\
Reforestation - Pinus & 0.71 & 0.10 & 0.00 & 0.00 & 0.00 & 0.00 & 0.00 & 0.00 \\
Uncovered Soil & 1.82 & 1.96 & 1.14 & 0.61 & 0.27 & 0.67 & 0.61 & 0.19 \\
\hline
\end{tabular}

\subsubsection{Basin Area}

The hydrographic basins areas were appropriated from the file containing the Level 6 Ottobacias watersheds limits, adopted for study area subdivision, as mentioned in the item "Study Area". From GIS files software manipulation, the regions areas were obtained by adopting Mercator Transversal Universal Projection System and SIRGAS Datum 2000. The areas values that resulted from the performed process are available in Table 3.

Table 3. Hydrographic regions' areas.

\begin{tabular}{cc}
\hline Hydrographic basin & Area $\left(\mathbf{k m}^{\mathbf{2}}\right)$ \\
\hline SB1 & 82.33 \\
SB2 & 39.70 \\
SB3 & 32.94 \\
SB4 & 40.34 \\
SB5 & 27.33 \\
SB6 & 57.82 \\
SB7 & 35.28 \\
SB8 & 17.77 \\
\hline
\end{tabular}

\subsubsection{Talveg Length}

The main hydrographic basins talveg lengths were appropriated by the sum of the stretches of the drainage network associated with the greatest length starting from the basins outlets. In order to characterize the drainage networks, information plans were used in the 1:50,000 and 1: 250,000 scales. The talveg lengths obtained by information plans manipulation are shown in Table 4 . The relative errors presented in this table were appropriated by comparison with the talveg lengths obtained from the larger scale $(1: 50,000)$ information plans. 
Table 4. Main talvegs hydrographic basins lengths.

\begin{tabular}{|c|c|c|c|c|c|}
\hline \multirow{2}{*}{$\begin{array}{l}\text { Hydrographic } \\
\text { region }\end{array}$} & \multirow[b]{2}{*}{ Main Talveg } & \multicolumn{2}{|c|}{ Talveg length $(\mathbf{k m})$} & \multicolumn{2}{|c|}{ Error } \\
\hline & & 1:50.000 & $1: 250.000$ & $\begin{array}{c}\text { Absolute } \\
(\mathbf{k m})\end{array}$ & $\begin{array}{l}\text { Relative } \\
(\%)\end{array}$ \\
\hline SB1 & Braço Norte Esquerdo River & 21.64 & 20.55 & 1.0982 & 5.07 \\
\hline SB2 & $\begin{array}{l}\text { Estrondo Creek e do Mata-Pau } \\
\text { Creek stretch }\end{array}$ & 13.36 & 13.12 & 0.2426 & 1.82 \\
\hline SB3 & $\begin{array}{l}\text { Sossego and Braço Norte } \\
\text { Esquerdo stretch }\end{array}$ & 10.768 & 10.68 & 0.0752 & 0.70 \\
\hline SB4 & $\begin{array}{l}\text { Piaçu Creek or Cantagalo and } \\
\text { Tombos Creek stretch }\end{array}$ & 10.46 & 10.26 & 0.1944 & 1.86 \\
\hline SB5 & $\begin{array}{l}\text { São João Creek and Córrego } \\
\text { Rico Creek stretch }\end{array}$ & 11.33 & 11.38 & 0.0456 & 0.40 \\
\hline SB6 & $\begin{array}{l}\text { Mata do Barão Creek and Braço } \\
\text { Norte Esquerdo stretch }\end{array}$ & 17.93 & 17.85 & 0.0747 & 0.42 \\
\hline SB7 & $\begin{array}{l}\text { Águas Claras Creek and } \\
\text { Ribeirão Vargem Grande } \\
\text { stretch }\end{array}$ & 13.49 & 12.06 & 1.4378 & 10.66 \\
\hline SB8 & $\begin{array}{c}\text { Seio de Abraão Creek and } \\
\text { Trecho do Braço Norte } \\
\text { Esquerdo stretch }\end{array}$ & 10.07 & 9.91 & 0.1630 & 1.62 \\
\hline
\end{tabular}

\subsubsection{Declivity}

Slope is a variable used in the application of different concentration time determination methods. Since most methods that present restrictions related to slope values employ the talveg mean slope to estimate concentration times, it was decided to use the talveg slope value as the standard criterion for formulas applicability analysis. In this context, the points coordinates corresponding to the headwater and outlet of the main watercourses of each sub-basin were taken into account, considering the drainage network layout available on the 1: 50,000 and 1: 250,000 scales information plans. Then, each main talveg head and outlet points altimetric dimensions were obtained, considering the different sources of information related to the relief. From the obtained altimetric dimensions, each of the main talvegs slope values was determined. The obtained dimensions and corresponding slope values are presented in Tables 5 (scale 1: 50,000) and 6 (scale 1: 250,000).

It is relevant to observe that the talveg slope is a physiographic characteristic that depends on two main factors: a) the drainage network or hydrography, which establishes the trajectory of the water courses and serves as basis for appropriating the talveg lengths; and b) the relief information, which provides information on altimetry. In this work, the information regarding the drainage network presents two different scales (1: 50,000 and 1: 250,000), and the information concerning the altimetric dimensions came from three different sources (level curves, 30-meter resolution DEM and 90-meter resolution DEM). In this way, each hydrographic basin presented six different possible slope values for the main talvegs.

\subsection{Concentration times estimation methods}

Indirect methods for concentration times determination were identified from a review of the literature. These methods were summarized by McCuen et al. (1984), Paiva and Paiva (2001), Pruski et al. (2004), DNIT (Brasil, 2005), Silveira (2005), Santos et al. (2009), Farias Junior and Botelho (2011), Grecco et al. (2012), Dhami and Pandey (2013) and Porto et al. (2014). The authors present, when available, information regarding each selected method's applicability and constraints. The variables basin occupation type (rural or urban), basin area, 
slope and talveg length - which determine concentration times appropriation indirect methods selection - and their respective reference values are shown in Table 7.

Table 5. Main talvegs slopes obtained from hydrography on 1: 50,000 scale data source.

\begin{tabular}{|c|c|c|c|c|c|c|c|c|c|}
\hline \multirow[b]{2}{*}{$\begin{array}{l}\text { Hydrographic } \\
\text { region }\end{array}$} & \multicolumn{3}{|c|}{ Headwater level (m) } & \multicolumn{3}{|c|}{ Exudation level (m) } & \multicolumn{3}{|c|}{ Slope $(\mathbf{m} / \mathbf{m})$} \\
\hline & $\begin{array}{c}\text { DEM } \\
30 \mathrm{~m}\end{array}$ & $\begin{array}{l}\text { DEM } \\
90 \mathrm{~m}\end{array}$ & DTM & $\begin{array}{l}\text { DEM } \\
\mathbf{3 0 ~} \mathbf{m}\end{array}$ & $\begin{array}{l}\text { DEM } \\
90 \mathrm{~m}\end{array}$ & DTM & $\begin{array}{l}\text { DEM } \\
30 \mathrm{~m}\end{array}$ & $\begin{array}{l}\text { DEM } \\
90 \mathrm{~m}\end{array}$ & DTM \\
\hline SB1 & 1236 & 1275 & 1208.8 & 606 & 624 & 617.6 & 0.0291 & 0.0301 & 0.0273 \\
\hline SB2 & 1309 & 1371 & 1302.1 & 606 & 624 & 617.6 & 0.0526 & 0.0559 & 0.0512 \\
\hline SB3 & 1015 & 1049 & 1046.5 & 523 & 536 & 530.6 & 0.0457 & 0.0477 & 0.0480 \\
\hline SB4 & 1262 & 1250 & 1264.4 & 523 & 536 & 530.6 & 0.0707 & 0.0683 & 0.0702 \\
\hline SB5 & 990 & 1051 & 1016.7 & 487 & 508 & 491,2 & 0.0444 & 0.0479 & 0.0464 \\
\hline SB6 & 998 & 989 & 1000.5 & 405 & 419 & 399.9 & 0.0331 & 0.0318 & 0.0335 \\
\hline SB7 & 654 & 734 & 670.4 & 405 & 419 & 399.9 & 0.0185 & 0.0233 & 0.0200 \\
\hline SB8 & 1326 & 1352 & 1318.5 & 377 & 396 & 369.4 & 0.0942 & 0.0949 & 0.0943 \\
\hline
\end{tabular}

Note: DEM - Digital Elevation Model; DTM - Digital Terrain Model.

Table 6. Main talvegs slopes obtained from hydrography on 1: 1:250,000 scale data source.

\begin{tabular}{|c|c|c|c|c|c|c|c|c|c|}
\hline \multirow[b]{2}{*}{$\begin{array}{l}\text { Hydrographic } \\
\text { region }\end{array}$} & \multicolumn{3}{|c|}{ Headwater level (m) } & \multicolumn{3}{|c|}{ Exudation level (m) } & \multicolumn{3}{|c|}{ Slope $(\mathbf{m} / \mathbf{m})$} \\
\hline & $\begin{array}{c}\text { DEM } \\
30 \mathrm{~m}\end{array}$ & $\begin{array}{c}\text { DEM } \\
90 \mathrm{~m}\end{array}$ & DTM & $\begin{array}{l}\text { DEM } \\
\mathbf{3 0 ~} \mathbf{m}\end{array}$ & $\begin{array}{l}\text { DEM } \\
90 \mathrm{~m}\end{array}$ & DTM & $\begin{array}{l}\text { DEM } \\
\mathbf{3 0 ~} \mathbf{m}\end{array}$ & $\begin{array}{l}\text { DEM } \\
90 \mathrm{~m}\end{array}$ & DTM \\
\hline SB1 & 1302 & 1333 & 1 & 609 & 617 & 6 & 0.0337 & 0.0348 & 0.0344 \\
\hline SB2 & 1362 & 1377 & 136 & 609 & 617 & 617.6 & 0.0574 & 0.0 & 0.0569 \\
\hline SB3 & 1038 & 1066 & 1058.9 & 529 & 536 & 533.8 & 0.0476 & 0.0496 & 0.0492 \\
\hline SB4 & 1247 & 1261 & 1259.6 & 529 & 536 & 533.8 & 0.0699 & 0.0706 & 0.0707 \\
\hline SB5 & 1066 & 1100 & 1116.4 & 488 & 499 & 489.7 & 0.0508 & 0.0528 & 0.0551 \\
\hline SB6 & 994 & 979 & 997.6 & 405 & 417 & 399.9 & 0.0330 & 0.0315 & 0.0335 \\
\hline SB7 & 702 & 676 & 687.1 & 405 & 417 & 399.9 & 0.0246 & 0.0215 & 0.0238 \\
\hline SB8 & 1332 & 1352 & 1324.8 & 384 & 396 & 371.8 & 0.0957 & 0.0965 & 0.0962 \\
\hline
\end{tabular}

Note: DEM - Digital Elevation Model; DTM - Digital Terrain Model.

\subsection{Concentration times}

As previously cited, concentration times calculation methods that exhibited in one or more study areas catchment area restrictions related to at least one criteria were considered unsuitable, and were disregarded as options for concentration times determination. Considering this perspective, Kirpich, California Culverts Practice, Federal Aviation Agency, Kinematic Wave, SCS Lag, Dooge, Ven Te Chow, Izzard, Arnell, Jhonstone, Tsuchiya, DNOS, Carter Lag equation for partially sewered, McCuen, IPH-II and Denver methods were not employed.

There were also disregarded methods that showed "Restriction unidentified" status for all criteria, as observed for the SCS - kinematic method, Giandotti, Pasini and Hathaway methodologies.

Among the remaining methods (Picking, Bransby-Williams, Riverside Country, US Corps of Engineers, Williams, Ventura, Putnam, Tulsa District and George Ribeiro), three were selected to estimate the study area's hydrographic basins' concentration times. The selected methods were George Ribeiro (method that proved to be applicable under all five criteria), Tulsa District (which showed to be applicable according to three of the four criteria) and US Corps of Engineers method (selected from the methods that were considered applicable under one of the analysis criteria and without use restrictions considering the other criteria). 
Table 7. Criteria for application of concentration time appropriation methods.

\begin{tabular}{|c|c|c|c|c|}
\hline Métodos & $\begin{array}{l}\text { Occupation } \\
\text { Type }\end{array}$ & $\operatorname{Area}\left(\mathbf{k m}^{2}\right)$ & $\begin{array}{l}\text { Declivity } \\
(\%)\end{array}$ & $\begin{array}{c}\text { Talvegue Length } \\
\text { (km) }\end{array}$ \\
\hline Kirpich & Rural & $<0.50$ & $3-10$ & $<10$ \\
\hline California Culverts Practice & Rural & $<0.50$ & $3-10$ & $<10$ \\
\hline Federal Aviation Agency & Urban & - & - & $0.015-0.030$ \\
\hline Kinematics wave & Urban & $\begin{array}{c}\text { Similar to Rational } \\
\text { Method }\end{array}$ & - & - \\
\hline SCS Lag & Rural & $<8$ & - & - \\
\hline SCS - Kinematics Method & - & - & - & - \\
\hline Dooge & Rural & $140-930$ & - & - \\
\hline Ven Te Chow & Rural & $<24.28$ & - & - \\
\hline Picking & Rural & - & - & - \\
\hline Izzard & Urban & - & $<4$ & $<0.02$ \\
\hline Giandotti & - & - & - & - \\
\hline Arnell & Urban & $0.20-50$ & - & - \\
\hline Bransby-Williams & Rural & - & - & - \\
\hline Jhonstone & Rural & $65-4,200$ & - & $1-$ \\
\hline Tsuchiya & Rural/Urban & $0.001-0.002$ & - & - \\
\hline Riverside Country & - & $5-1,600$ & - & - \\
\hline Pasini & - & - & - & - \\
\hline DNOS & - & 0.45 & $3-10$ & $<1.20$ \\
\hline US Corps of Engineers & - & $<3,000$ & - & - \\
\hline $\begin{array}{l}\text { Carter Lag equation for } \\
\text { Partially Sewered }\end{array}$ & Urban & $<20.70$ & $<0.50$ & $<11.26$ \\
\hline Williams & - & $<129.50$ & - & - \\
\hline Ventura & Rural & - & - & - \\
\hline McCuen & Urban & $0.40-16$ & $<4$ & $<10$ \\
\hline IPH-II & Urban & $2.50-137$ & - & - \\
\hline Putnam & - & $0.75-340$ & - & - \\
\hline Tulsa District & - & $1-1,300$ & $0.08-18$ & $1.60-96$ \\
\hline Denver & - & $<13$ & Moderada & - \\
\hline George Ribeiro & Rural & $<19,000$ & $1-10$ & $<250$ \\
\hline Hathaway & - & - & - & - \\
\hline
\end{tabular}

Source: Adapted from McCuen et al. (1984), Paiva e Paiva (2001), Pruski et al. (2004), DNIT (Brasil, 2005), Silveira (2005), Santos et al. (2009), Farias Junior e Botelho (2011), Grecco et al. (2012), Dhami and Pandey (2013) and Porto et al. (2014).

The concentration times obtained by using the three selected methods are assembled in Tables 8 and 9. Table 8 shows the values obtained by using the hydrographic information available for the 1: 50,000 scale information plans. Table 9, on the other hand, presents the values corresponding to the use of hydrography in 1: 250,000 scale information plans.

From simple inspection of Tables 8 and 9, it can be observed that the concentration times values for each hydrographic basin present variations that depend on the selected method for concentration time appropriation, the spatial resolution used to describe relief employed in the slope appropriation and drainage network scale. In both tables, it is possible to observe that the influence of the concentration time appropriation method is less significant for the SB1, SB2 and SB8 hydrographic basins. In all others, the comparison with the other methods adopted presents a difference greater than $10 \%$ in the estimated time of concentration. 
Table 8. Concentration times (minutes) obtained from 1:50,000 scale hydrography.

\begin{tabular}{cccccccccc}
\hline & \multicolumn{9}{c}{ Concentration time (min) } \\
\cline { 2 - 10 } $\begin{array}{c}\text { Hydrographic } \\
\text { region }\end{array}$ & \multicolumn{1}{c}{ US Corps of Engineers } & \multicolumn{3}{c}{ Tulsa District } & \multicolumn{3}{c}{ George Ribeiro } \\
\cline { 2 - 10 } & DEM & DEM & DTM & DEM & DEM & DTM & DEM & DEM & DTM \\
& $\mathbf{3 0}$ & $\mathbf{9 0}$ & & $\mathbf{3 0}$ & $\mathbf{9 0}$ & & $\mathbf{3 0}$ & $\mathbf{9 0}$ & \\
\cline { 2 - 10 } SB1 & 372.65 & 371.62 & 378.63 & 377.54 & 376.47 & 383.76 & 350.99 & 350.94 & 351.08 \\
SB2 & 219.76 & 219.25 & 222.05 & 238.60 & 238.03 & 241.15 & 218.49 & 218.44 & 218.52 \\
SB3 & 237.05 & 230.41 & 238.91 & 252.67 & 245.40 & 254.70 & 167.63 & 167.61 & 167.60 \\
SB4 & 187.08 & 185.75 & 188.91 & 210.26 & 208.74 & 212.37 & 170.70 & 170.73 & 170.71 \\
SB5 & 218.00 & 216.25 & 217.43 & 232.46 & 230.54 & 231.84 & 176.70 & 176.65 & 176.67 \\
SB6 & 375.46 & 378.30 & 379.34 & 370.35 & 373.23 & 374.28 & 284.72 & 284.76 & 284.71 \\
SB7 & 277.60 & 272.87 & 278.32 & 321.90 & 316.27 & 322.77 & 215.57 & 215.37 & 215.50 \\
SB8 & 178.04 & 177.20 & 177.12 & 178.73 & 177.86 & 177.78 & 163.25 & 163.24 & 163.25 \\
\hline
\end{tabular}

Table 9. Concentration times (minutes) obtained from 1:250,000 scale hydrography.

\begin{tabular}{ccccccccccc}
\hline & \multicolumn{10}{c}{ Concentration time (min) } \\
\cline { 2 - 10 } $\begin{array}{c}\text { Hydrographic } \\
\text { region }\end{array}$ & \multicolumn{9}{c}{ US Corps of Engineers } & \multicolumn{3}{c}{ Tulsa District } & \multicolumn{3}{c}{ George Ribeiro } \\
\cline { 2 - 11 } & DEM & DEM & DTM & DEM & DEM & DTM & DEM & DEM & DTM \\
& $\mathbf{3 0}$ & $\mathbf{9 0}$ & & $\mathbf{3 0}$ & $\mathbf{9 0}$ & & $\mathbf{3 0}$ & $\mathbf{9 0}$ & \\
\cline { 2 - 11 } SB1 & 359.31 & 356.15 & 363.41 & 372.68 & 369.32 & 377.06 & 332.98 & 332.94 & 332.96 \\
SB2 & 217.10 & 215.72 & 218.94 & 238.74 & 237.18 & 240.81 & 214.45 & 214.45 & 214.46 \\
SB3 & 234.81 & 226.20 & 235.81 & 250.12 & 240.71 & 251.22 & 166.44 & 166.41 & 166.42 \\
SB4 & 183.71 & 181.50 & 185.01 & 208.35 & 205.79 & 209.87 & 167.54 & 167.53 & 167.53 \\
SB5 & 216.46 & 213.09 & 215.40 & 231.37 & 227.67 & 230.20 & 177.32 & 177.29 & 177.26 \\
SB6 & 371.81 & 371.06 & 374.37 & 369.17 & 368.40 & 371.77 & 283.54 & 283.59 & 283.52 \\
SB7 & 257.04 & 251.62 & 257.40 & 310.14 & 303.43 & 310.59 & 192.38 & 192.48 & 192.40 \\
SB8 & 175.24 & 174.03 & 174.31 & 176.97 & 175.72 & 176.01 & 160.60 & 160.59 & 160.59 \\
\hline
\end{tabular}

In order to evaluate concentration time-value variations, a reference scenario was established, corresponding to the concentration times obtained from the information plans presenting larger scale or resolution and by the method applicable considering all criteria. This scenario was composed by the concentration time determined by the George Ribeiro method (method usually employed in urban drainage studies in Brazil), using 1:50,000 scale hydrography and digital terrain model appropriated from the 20-meter equidistant contours (sources with higher levels of detailing for hydrography and digital terrain model).

The concentration time percentage value variations in relation to the reference scenario are shown in Table 10.

The values presented in Table 10 indicate that the different concentration time method combinations (US Corps of Engineers. Tulsa District and George Ribeiro) used for hydrography description scale (1: 50,000 and 1: 250,000) and local relief description alternatives (DEM 30 m. DEM 90m and DTM) produced values that varied from approximately $-11 \%$ (underestimation associated with SB7 when compared to the referential scenario, when using the George Ribeiro method and 1: 250,000 hydrography) and + 52\% (overestimate for SB3, Tulsa District method and 1: 50,000 hydrography).

In addition, the following observations are considered relevant: a) the scale variation associated with hydrography produced percentage variations in concentration time values invariably lower than $11 \%$ (the greatest variations were estimated for SB7, when using the George Ribeiro method and 30m digital elevation model); and b) the change in the relief representation, retained the scale associated with hydrography and concentration time 
estimation method, did not produce variations greater than $6 \%$, regardless the analyzed combination; and c) the concentration time appropriation methods, maintaining relief and hydrography representation forms, produced maximum variations greater than $50 \%$ (variations estimated for SB7, when considering errors referring to Tulsa District and George Ribeiro methods).

Table 10. Percentage variations in relation to the referential scenario.

\begin{tabular}{|c|c|c|c|c|c|c|c|c|c|c|}
\hline \multirow{3}{*}{$\begin{array}{l}\text { Hydrographic } \\
\text { basin }\end{array}$} & \multirow{3}{*}{ Hydrography } & \multicolumn{9}{|c|}{ Percentage Variations } \\
\hline & & \multicolumn{3}{|c|}{ US Corps of Engineers } & \multicolumn{3}{|c|}{ Tulsa District } & \multicolumn{3}{|c|}{ George Ribeiro } \\
\hline & & $\begin{array}{l}\text { DEM } \\
30 \mathrm{~m}\end{array}$ & $\begin{array}{l}\text { DEM } \\
90 \mathrm{~m}\end{array}$ & DTM & $\begin{array}{l}\text { DEM } \\
30 \mathrm{~m}\end{array}$ & $\begin{array}{l}\text { DEM } \\
90 \mathrm{~m}\end{array}$ & DTM & $\begin{array}{l}\text { DEM } \\
30 \mathrm{~m}\end{array}$ & $\begin{array}{l}\text { DEM } \\
90 \mathrm{~m}\end{array}$ & DTM \\
\hline SB1 & \multirow{8}{*}{$1: 50.000$} & 6.15 & 5.85 & 7.85 & 7.54 & 7.23 & 9.31 & -0.03 & -0.04 & \multirow{8}{*}{$\begin{array}{c}\text { Reference } \\
\text { Scenario }\end{array}$} \\
\hline SB2 & & 0.57 & 0.34 & 1.62 & 9.19 & 8.93 & 10.36 & -0.01 & -0.04 & \\
\hline SB3 & & 41.44 & 37.47 & 42.55 & 50.76 & 46.42 & 51.97 & 0.02 & 0.00 & \\
\hline SB4 & & 9.59 & 8.81 & 10.66 & 23.17 & 22.28 & 24.41 & 0.00 & 0.01 & \\
\hline SB5 & & 23.39 & 22.40 & 23.07 & 31.58 & 30.49 & 31.23 & 0.02 & -0.01 & \\
\hline SB6 & & 31.88 & 32.88 & 33.24 & 30.08 & 31.09 & 31.46 & 0.01 & 0.02 & \\
\hline SB7 & & 28.82 & 26.62 & 29.15 & 49.38 & 46.76 & 49.78 & 0.03 & -0.06 & \\
\hline SB8 & & 9.06 & 8.55 & 8.50 & 9.48 & 8.95 & 8.90 & 0.00 & 0.00 & \\
\hline SB1 & \multirow{8}{*}{$1: 250.000$} & 2.34 & 1.44 & 3.51 & 6.15 & 5.20 & 7.40 & -5.15 & -5.17 & -5.16 \\
\hline SB2 & & -0.65 & -1.28 & 0.19 & 9.25 & 8.54 & 10.20 & -1.86 & -1.86 & -1.86 \\
\hline SB3 & & 40.10 & 34.96 & 40.70 & 49.24 & 43.62 & 49.89 & -0.70 & -0.71 & -0.71 \\
\hline SB4 & & 7.61 & 6.32 & 8.38 & 22.05 & 20.55 & 22.94 & -1.86 & -1.86 & -1.86 \\
\hline SB5 & & 22.52 & 20.62 & 21.92 & 30.96 & 28.87 & 30.30 & 0.37 & 0.35 & 0.33 \\
\hline SB6 & & 30.60 & 30.33 & 31.49 & 29.67 & 29.40 & 30.58 & -0.41 & -0.39 & -0.42 \\
\hline SB7 & & 19.28 & 16.76 & 19.44 & 43.92 & 40.81 & 44.12 & -10.73 & 10.68 & -10.72 \\
\hline SB8 & & 7.35 & 6.60 & 6.78 & 8.41 & 7.64 & 7.82 & -1.63 & -1.63 & -1.63 \\
\hline
\end{tabular}

\section{CONCLUSIONS}

The study identified concentration times appropriation methods applicable to the hydrographic basins that comprise part of the study area, considering soil occupation, area, length and slope of the main talveg characteristics. Among the identified methods, George Ribeiro, Tulsa District and US Corps of Engineers were considered more appropriate, in the order in which they were mentioned.

The estimated concentration times varied up to $11 \%$ considering the variables calculated from different information plans and varied up to $52 \%$ considering the variables calculated from different concentration times methods. It was also possible to conclude that there is equivalence between Tulsa District and US Corps of Engineers equations for the hydrographic study basin, and that change of information source related to relief and hydrography did not significantly affect the concentration times appropriation. The adequate concentration times values large importance for drainage systems design and the differences in results obtained by different models in this study shows the importance of field surveys for obtaining information that could contribute to model choice and calibration.

\section{BIBLIOGRAPHIC REFERENCES}

BRASIL. Departamento Nacional de Infra-Estrutura de Transportes - DNIT. Manual de Hidrologia Básica para Estruturas de drenagem. Rio de Janeiro, 2005.

CABRAL, S. L.; SAKURAGI, J.; SILVEIRA, C. S. Incertezas e erros na estimativa de vazões usando modelagem hidrológica e precipitação por RADAR. Revista Ambiente \& Água, v. 12, n. 1, p. 57-70, 2017. http://dx.doi.org/10.4136/ambi-agua.1924 
DHAMI, B. S.; PANDEY, A. Comparative review of recently developed hydrologic models. Journal of Indian Resources Society, v. 33, n. 3, p.34-42, 2013.

FAN, F. M.; COLLISCHONN, W. Integração do modelo MGB-IPH com sistema de informação geográfica. Revista Brasileira de Recursos Hídricos, v. 19, n. 1, p. 243 254, 2014.

FARIAS JUNIOR, J. E. F.; BOTELHO, R. G. M. Análise comparativa do tempo de concentração: estudo de caso rio Cônego, município de Nova Friburgo/RJ. In: SIMPÓSIO BRASILEIRO DE RECURSOS HIDRÍCOS, 19, 2011. Anais... Maceió: Associação Brasileira de Recursos Hídricos, 2011. 1 CD-ROM.

FERRAZ, F. F. B.; MILDE, L. C. E.; MORATTI, J. Modelos hidrológicos acoplados a sistemas de informações geográficas: um estudo de caso. Revista de Ciência \& Tecnologia, v. 7, n. 14, p. 45-56, 1999.

FITZ, P. R. Geoprocessamento sem complicação. São Paulo: Oficina de Textos, 2008.

GRECCO, L. B.; MANDELLI, M. S.; REIS, J. A. T.; MENDONÇA, A. S. F. Influência da Seleção de Variáveis Hidrológicas no Projeto de Sistemas Urbanos de Macrodrenagem Estudos de Caso para o Município de Vitória - ES. Revista Brasileira de Recursos Hídricos, v. 17, n. 4, p. 197-206, 2012.

HALWATURA, D.; NAJIM, M. M. M. Application of HEC-HMS model for runoff simulation in a tropical catchment. Environmental Modelling \& Software, v. 46, p. 155-162, 2013.

INSTITUTO CAPIXABA DE PESQUISA, ASSISTÊNCIA TÉCNICA E EXTENSÃO RURAL - INCAPER. Hidrometeorologia. 2011. Disponível em: http://hidrometeorologia.incaper.es.gov.br/caracterizacao/cacho_itap_carac.php. Acesso em: 13 abr. 2012.

MATA-LIMA, H.; VARGAS, H.; CARVALHO, J.; GONÇALVES, M.; CAETANO, H.; MARQUES, A. et al. Comportamento hidrológico de bacias hidrográficas:integração de métodos e aplicação a um estudo de caso. Revista da Escola de Minas, v. 60, n. 3, p. 525-536, 2007.

MCCUEN, R. H.; WONG, S. L.; RAWLS, W. J. Estimating urban time of concentration. Journal of Hydraulic Engineering, v. 110, n. 7, p. 887-904, 1984. https://doi.org/10.1061/(ASCE)0733-9429(1984)110:7(887)

PAIVA, J.B.D.; PAIVA, E. M. C. D. (Org.). Hidrologia aplicada à gestão de pequenas bacias hidrográficas. Porto Alegre: ABRH, 2001.

PORTO, R. et al., Drenagem urbana. In: TUCCI, C. E. M. (Org.). Hidrologia: ciência e aplicação. Porto Alegre: ABRH, 2014.

PRUSKI, F. F.; BRANDÃO, V. S.; SILVA, D. D. Escoamento superficial. Viçosa: Editora UFV, 2004.

SANTOS, G. G.; FIGUEIREDO, C. C.; OLIVEIRA, L. F. C.; GRIEBELER, N. P. Intensidadeduração-frequência de chuvas para o Estado de Mato Grosso do Sul. Revista Brasileira de Engenharia Agrícola e Ambiental, v. 13, p. 899-905, 2009. http://dx.doi.org/10.1590/S1415-43662009000700012 
SHUSTER, W. D.; PAPPAS, E. Laboratory simulation of urban runoff and estimation of runoff hydrographs with experimental curve numbers implemented in USEPA SWMM. Journal of Irrigation and Drainage Engineering, v. 137, n. 6, p. 343-351, 2010. https://doi.org/10.1061/(ASCE)IR.1943-4774.0000301

SILVA, M. M. G. T.; WEERAKOON, S. B.; HERATH, S. Modelling of event and continuous flow hydrographs with HEC-HMS: case study in Kelani River Basin, Sri Lanka. Journal $\begin{array}{llllllll}\text { of Hydrologic Engineering, v. 19, n. 4, p. 800-806, } 2014 . & \text {. }\end{array}$ https://doi.org/10.1061/(ASCE)HE.1943-5584.0000846

SILVEIRA, A. L. L. Desempenho de fórmulas de tempo de concentração em bacias urbanas e rurais. Revista Brasileira de Recursos Hídricos, v. 10, n. 1, p. 5-23, 2005.

VINAGRE, M. V. A.; LIMA, A. C. M.; LIMA JUNIOR, D. L. Estudo do comportamento hidráulico da bacia do Paracuri em Belém (PA) utilizando o programa Storm Water Management Model. Engenharia Sanitária e Ambiental, v. 20, n. 3, 2015.

WALSH, T. C.; POMEROY, C. A.; BURIAN, S. J. Hydrologic modeling analysis of a passive, residential rainwater harvesting program in an urbanized, semi-arid watershed. Journal of Hydrology, v. 508, p. 240-253, 2014. https://doi.org/10.1016/j.jhydrol.2013.10.038 